\title{
Effects of short-term Pilates exercise on selected blood parameters
}

\author{
Paulina Gronesova ${ }^{1}$, Danka Cholujova ${ }^{1}$, Katarina Kozic $^{1}$, Michaela Korbuly ${ }^{1}$, Miroslav Vlcek ${ }^{2}$, \\ Adela Penesova ${ }^{2}$, Richard Imrich ${ }^{2}$, Jan Sedlak ${ }^{1}$ and Luba Hunakova ${ }^{1}$ \\ ${ }^{1}$ Cancer Research Institute, Biomedical Research Center, Slovak Academy of Sciences, Bratislava, Slovakia \\ ${ }^{2}$ Institute for Clinical and Translational Research, Biomedical Research Center, Slovak Academy of Sciences, Bratislava, \\ Slovakia
}

\begin{abstract}
The aim of our prospective, interventional, pre-post, single arm study was to supplement the lack of knowledge of the effect of short-term Pilates intervention on selected blood parameters of healthy women. Female volunteers were recruited for 2-weeks Pilates intervention. Blood has been collected and anthropometric parameters were measured before and after exercise period (EP). Plasma insulin, cortisol, and dehydroepiandrosterone sulphate levels, erythrocyte antioxidant activity, glutathione levels, NK cytotoxicity and plasma cytokines were analysed. We found a decrease in erythrocyte antioxidant enzymes SOD and GPx activity; GSH levels; in the pro-inflammatory chemokine MCP-1 and trend to reduction in MIP-1 $\beta$, PDGF and VEGF levels in plasma. NK cell cytotoxic activity increased after Pilates EP in the percentage of specific lysis at 25:1 effector: target (E:T) ratio and the same trend was observed at all E:T ratios as well as in the amount of lytic units per 107 cells. Our findings show that Pilates exercise may improve NK cell immune response and inflammatory milieu in plasma of healthy women.
\end{abstract}

Key words: Pilates — Inflammation - MCP-1 - NK cells

\section{Introduction}

Physical activity can positively influence and treat a variety of diseases associated with life style and those, that have a common inflammatory basis like type 2 diabetes, atherosclerosis, cancer, and others (Pradhan et al. 2002). Exercise reduces the risk of cardiovascular diseases (coronary artery disease, chronic heart failure and atherosclerosis) mortality by $35 \%$ (Nocon et al.2008); reduces the risk of the overall incidence of diabetes and metabolic syndrome by $58 \%$ (Tuomilehto et al. 2001). It has preventive effects on weight control, the development of mental illnesses such as dementia (Rovio et al. 2005) and depression (Paffenbarger et al. 1994), and has a positive effect on muscle and bone strength, preventing osteoarthritis and osteoporosis.

Recent epidemiological studies have demonstrated an evident association between exercise and physical activity

Correspondence to: Luba Hunakova, Cancer Research Institute, Biomedical Research Center, Slovak Academy of Sciences, Dubravska cesta 9, 84505 Bratislava, Slovakia

E-mail: luba.hunakova@savba.sk
(PA) with markedly reduced cancer-related, and overall mortality, in various cancers, including breast, colon, and prostate (Holmes et al. 2005; Meyerhardt et al. 2006; Kenfield et al. 2011).

Evidence from observational studies has shown that physical activity reduces the risk of disease recurrence in colorectal, prostate, and breast cancer patients (Meyerhardt et al. 2006; Irwin et al. 2008; Friedenreich et al. 2016) and may be associated with a reduced risk of lung cancer (Brenner et al. 2016). Several mechanisms have been proposed, including reduced oxidative stress, the modification of metabolic hormone levels via a reduction in fat-produced estrogens, and a reduced contact with carcinogens through increased ventilation (Friedenreich and Orenstein 2002; Quadrilatero and Hoffman-Goetz 2003; Kruk and AboulEnein 2006).

The immune response to exercise is complex and specific to various components of the immune system, e.g. cells of the adaptive branch of the immune system (T lymphocytes and B lymphocytes); cells of the innate branch (monocytes, granulocytes, NK cells), and soluble factors such as immunoglobulins and cytokines/chemokines. 
Chemokine-binding proteins modulate immune responses through target cell surface receptors. This mechanism is similar to hormonal and may lead to new therapeutic approaches for treatment of inflammatory diseases.

Physical activity is of four main types: $\mathrm{i} /$ aerobic (endurance), ii/ muscle-strengthening, iii/ bone-strengthening, and iv/ stretching. The intensity of the aerobic activities is divided into three groups: light, moderate or vigorous.

Pilates is one type of physical activity systems developed in the early 1920s by Joseph Hubertus Pilates. It has developed in combination with Yoga, Zen and the regimens of ancient Greece and Rome (Latey 2001). Pilates improves balance (Marandi et al. 2013), flexibility (Phrompaet et al. 2011) and recently, according to a systematic review by Wells et al. (2012), it has been found that Pilates exercises improves center stability, strength, flexibility, muscle coordination, posture, breathing, etc. It also develops control and endurance in the entire body, including the erector spinae (Sekendiz et al. 2007), and it trains the mind and body organically through breathing exercises (Muscolino and Cipriani 2004). Pilates has been shown to improve muscle strength and balance (Granacher et al. 2013) and to increase bone mineral density (BMD) (Pilates Exercises for Osteoporosis - Osteoporosis Center - Everyday Health, available at: http://www.everydayhealth.com/osteoporosis/ pilates-exercises-for-osteoporosis.aspx; Angin et al. 2015) and thus to prevent osteoporosis.

The aim of this prospective, interventional, pre-post, single arm study was, therefore, to determine the effects of short-term (two weeks) Pilates physical activity, of healthy women, on their plasma cytokines levels, NK cell cytotoxicity, and the erythrocyte activities of antioxidant enzymes and selected endocrine parameters.

Table 1. Clinical characteristics of the study subjects

\begin{tabular}{lcc}
\hline Parameter & $\begin{array}{c}\text { Before EP } \\
(n=10)\end{array}$ & $\begin{array}{c}\text { After EP } \\
(n=10)\end{array}$ \\
\hline Age (years) & $46 \pm 3$ & $46 \pm 3$ \\
Body weight $(\mathrm{kg})$ & $62.2 \pm 3.0$ & $62.8 \pm 3.0$ \\
BMI $\left(\mathrm{kg} / \mathrm{m}^{2}\right)$ & $22.9 \pm 1.2$ & $23.1 \pm 1.2$ \\
BF $(\%)$ & $30 \pm 2$ & $32 \pm 3$ \\
MET (h/day) & $37 \pm 6$ & $40 \pm 6$ \\
EE (kCal/24 h) & $2707 \pm 708$ & $2986 \pm 628$ \\
Morning fasting plasma cortisol (nmol/l) & $234 \pm 26$ & $282 \pm 30$ \\
Fasting plasma insulin (mIU/l) & $2.92 \pm 0.69$ & $5.63 \pm 2.11$ \\
DHEAS (mmol/l) & $3.45 \pm 0.54$ & $3.55 \pm 0.55$ \\
\hline
\end{tabular}

The data are expressed as mean $\pm \mathrm{SD}$. BF\%, body fat percentage; EP, exercise period; BMI; body mass index; BF, body fat; MET, metabolic energy turnover; EE, energy expenditure estimated using activity score according to Lagerros et al. (2006); DHEAS, dehydroepiandrosterone sulphate.

\section{Subjects and Methods}

\section{Study population}

Initially, 13 volunteers recruited from the staff of the Cancer Research Institute of the Slovak Academy of Sciences, were included in the study; 10 underwent all examinations and interventions. Most of them did not take any medication; two probands were on substitutional therapy with L-thyroxine due to hypothyroidism. The inclusion criteria were volunteers without any cancer history, healthy adults (age between 20-65 years). Participants with a history of cardiovascular disease, hypertension, diabetes mellitus (type I and II), current smoking, hepatic or renal disease, acute or chronic infection were excluded from the study. The examinations were performed at the Biomedical Center, Institute of Clinical and Translational Research, Slovak Academy of Sciences. The basic clinical characteristics of all the study subjects are given in Table 1. All subjects gave informed written consent and the study was approved by the Ethics Committee of the Bratislava Self-Governing Region, Bratislava, Slovakia (106605/2014-ZDR), in accordance with the ethical guidelines of the Declaration of Helsinki, as revised in 2000.

\section{Study design, sample collection and preparation}

A prospective, interventional, pre-post, single arm research design was used. The examinations started in the morning at 08:00 AM. The subjects were asked to fast for 12 hours and restrain from incurring stress or doing any intensive physical activity $24 \mathrm{~h}$ before the study. Upon arrival in the outpatient's clinic, a baseline personal history was taken and body weight, height, body fat percentage (Omron 511BF, OMRON HEALTHCARE Co., Ltd. Kyoto, Japan) and waist circumference were measured. Thereafter, the cubital vein was cannulated (Terumo Europe N.V., Leuven, Belgium) and subjects rested for $30 \mathrm{~min}$ in a comfortable chair to relieve acute stress from the venipuncture. Their blood pressure (Dinamap Vital Sign Monitor, model 845 XT, Criticon X, Inc., Tampa, FL, USA) was measured on the arm during the rest. The blood of the probands was collected before the exercise period (ordinary physical activity period), and after 2 weeks of increased Pilates physical activity. Blood was collected into polyethylene tubes with EDTA as an anticoagulant and immediately cooled on ice. For immune assay analyses, the blood was centrifuged $\left(1200 \times g, 10 \mathrm{~min}\right.$, and $\left.4^{\circ} \mathrm{C}\right)$ and all plasma aliquots were stored at $-80^{\circ} \mathrm{C}$ until assayed. Plasma samples for cytokine analyses were prepared from peripheral blood $(1 \mathrm{ml})$ by centrifugation at $1200 \times g$ for $10 \mathrm{~min}$, at room temperature. The supernatants were collected and filtered through sterile $0.22 \mu \mathrm{m}$ filters, and aliquots were stored at $-80^{\circ} \mathrm{C}$ until analysis. The erythrocytes for the determination of SOD and GPx activity were isolated from whole blood by 
three-fold washing in a cold PBS solution and centrifugation at $800 \times g$ for $10 \mathrm{~min}$, at $4^{\circ} \mathrm{C}$. Aliquots were stored at $-80^{\circ} \mathrm{C}$ until analysis. Flow cytometry-based cytotoxicity assay was performed directly from fresh, non-frozen blood.

\section{Determination of physical activity}

Physical activity level (PAL) was assessed using a Slovak version of the Lagerro's questionnaire (Lagerros et al. 2006). Physical activity during an average weekday was estimated using an instrument with nine physical activity steps, which graded physical activity according to its intensity. Each step was assigned a value expressed as a multiple of Metabolic Energy Turnover (MET) and exemplified by common activities. Participants were instructed to report the time they spent on each intensity level during an average day and night; hence, the total physical activity time should add up to $24 \mathrm{~h}$ and allow for an estimate of MET ${ }^{\star}$ hours per day (MET h/day) and a total physical activity score calculated as the sum of the individual level activities $\left(\mathrm{MET}_{1}{ }^{\star} \mathrm{t}_{1}+\mathrm{MET}_{2}{ }^{\star} \mathrm{t}_{2}+\ldots+\mathrm{MET}_{9}{ }^{\star} \mathrm{t}_{9}\right.$, where $\mathrm{MET}_{\mathrm{i}}$ is assigned an MET value for the current level and $t$ is the time spent executing the current activity).

\section{Pilates exercise}

All the participants were instructed to exercise 180 minutes per week, under the supervision of a certified STOTT Pilates instructor. STOTT PILATES (the contemporary approach to the original Pilates method) offers varying levels of movement - essential, intermediate and advanced - to meet the exercise needs of all clients, from post-rehab to elite athlete. Energy expenditure in units of metabolic equivalent of tasks (METs) was assigned to this activity using the Compendium of Physical Activities. The intensity of each 60 minutes exercise, expressed in METs, corresponded to 6 METs (Ainsworth et al. 2000).

\section{Immunno assays}

Plasma insulin, cortisol, and dehydroepiandrosterone sulphate levels were measured using radioimmunoassay kits (Immunotech a.s., a Beckman Coulter company, Praha, Czech Republic), according to the manufacturer's instructions.

\section{Determination of superoxide dismutase activity}

For the determination of superoxide dismutase activity (SOD; EC1.15.1.1), we used the RANSOD kit. The method employs xanthine and xanthine oxidase to generate superoxide radicals, which react with 2-(4-iodophenyl)-3-(4nitrophenol)-5-phenyltetrazolium chloride to form a red formazan dye. The activity was measured by the degree of reaction inhibition.

\section{Determination of glutathione peroxidase activity}

For the determination of glutathione peroxidase activity (GPx, EC1.11.1.9), according to the method of Paglia and Valentine (Paglia and Valentine 1967), we used cumene hydroperoxide as a substrate.

\section{Glutathione assay}

Intracellular total glutathione was measured by flow cytometry (CANTO II, Becton Dickinson) using Monochlorobimane (MCB) staining for glutathione (GSH). $1-2 \times 10^{6}$ cells were stained with $40 \mu \mathrm{M} \mathrm{MCB}$ at room temperature for $20 \mathrm{~min}$. The cells were chilled by the addition of ice-cold $\mathrm{PBS}$ at $4^{\circ} \mathrm{C}$ to stop the enzyme-dependent staining reaction. Fluorescence of MCB-GSH conjugate was detected using a $405 \mathrm{~nm}$ excitation laser and a 450/50 emission bandpass filter. The cells were analysed by FCS Express 4.0 (de Novo) software. The relative fluorescence intensity (RFI) was expressed as a multiple of the fluorescence intensity of the control samples.

\section{Plasma cytokines analyses}

The plasma levels of 27 cytokines (IL-1b, IL-1 receptor antagonist (IL-1ra), IL-2, IL-4, IL-5, IL-6, IL-7, IL-8, IL-9, IL-10, IL-12p70, IL-13, IL-15, IL-17A, Eotaxin, Basic FGF, G-CSF, GM-CSF, IFN-g, IP-10, MCP-1, MIP-1a, MIP-1b, PDGF-BB, RANTES, VEGF and TNF- $a$ were analyzed using the Bio-Plex Suspension Array System (Bio-Rad Laboratories Inc., Hercules, CA, USA). The multiplex microbeads-based cytokine immunoassay was performed in 96-well filter microplates, according to the manufacturer's instructions. The cytokine standards and samples ( $50 \mu \mathrm{l}$ were diluted in plasma dilution buffer and incubated with fluorescently-labelled microspheres coupled to specific monoclonal antibodies ( $50 \mu \mathrm{l})$ for $30 \mathrm{~min}$ on a plate shaker $(300 \mathrm{rpm})$ in the dark). After one wash step, the beads were incubated with the biotinylated detection antibody cocktail ( $25 \mu \mathrm{l} /$ well $)$ for $30 \mathrm{~min}$, followed by streptavidin-PE ( $50 \mu \mathrm{l} /$ well $)$ for $10 \mathrm{~min}$. Finally, $125 \mu \mathrm{l}$ of assay buffer was added to each well before reading the plate on a Bio-Plex system. The cytokine concentrations were calculated using Bio-Plex Manager Software.

\section{Flow cytometry-based cytotoxicity assay}

The preparation of effector peripheral blood mononuclear cells (PBMCs) and target (K562 cells) cells was performed as previously described (Cholujova et al. 2008).

The NK cytotoxic activity in PBMCs from healthy individuals included in this study was determined against target K-562 cells using the calcein acetoxymethyl ester (CAM) assay. The target K562 cells were loaded with CAM (stock 
solution $1 \mathrm{mM}$ in DMSO) complete culture medium (consisting of RPMI 1640 medium, 2 mM L-glutamine, 100 IU/ml penicillin, $100 \mu \mathrm{g} / \mathrm{ml}$ streptomycin and supplemented with $10 \%$ fetal calf serum) and further incubated for $15 \mathrm{~min}$ at $37^{\circ} \mathrm{C}$ in the dark. After washing with PBS, the target K-562 cells $\left(2 \times 10^{4}\right.$ per well) were seeded in 96-well V-bottomed microplates in $50 \mu \mathrm{l}$ of $\mathrm{CM}$.

Appropriate six serial two-fold dilutions of effector cells (PBMCs) were made, from which $100 \mu \mathrm{l}$ aliquots were added to the K562 target cells to obtain the six effectors: target (E:T) ratios started at 50:1. Additionally, two sets of controls containing only effector cells or only target cells were prepared. The plates were centrifuged at $200 \times g$ for $3 \mathrm{~min}$ and incubated for $3 \mathrm{~h}$. The samples were then transferred into cytometric tubes and $2 \mu \mathrm{g} / \mathrm{ml}$ of 7 -AAD (stock solution $1 \mathrm{mg} / \mathrm{ml}$ in PBS) was added to mark the dead cells. The samples were incubated on ice for $10 \mathrm{~min}$, protected from light, and analyzed using a BD FACS CantoII flow cytometer. For the assessment of purified NK cell cytotoxicity, three 8:1, 4:1 and 2:1 effector (target ratios), an incubation time of $90 \mathrm{~min}$, and $10^{4}$ target $\mathrm{K} 562$ cells per well were used.

The cytotoxic activity toward the target K562 cells was determined based on the viable cells enumeration using flow cytometric data. The percentage of specific lysis (PSL) was calculated at each E:T ratio as follows: \% specific lysis = $(\mathrm{CT}-\mathrm{TE} / \mathrm{CT}) \times 100$ (CT, mean the number of fluorescent target cells in control tubes; TE, the mean number of fluorescent cells in target + effector tubes). A lytic unit (LU) is defined as the number of effector cells required to lyse $20 \%$ of a predetermined standard number (TSTD $=2 \times 10^{4}$ ) of target cells. The results were reported as the number of LU contained in a specified number of effector cells (ESTD = $\left.10^{7}\right)$. These calculations can be expressed by the formula: number of LU/10 7 effector cells = ESTD / (E:T20) $\times($ TSTD $)$, where e.g. E:T20 is the ratio at which $20 \%$ of the target cells are killed.

\section{Flow cytometry - Phenotyping}

Multi-parameter flow cytometry was performed using a lysed-whole-blood technique without isolation of cells

Table 2. Activities of antioxidant enzymes SOD, GPx and levels of GSH

\begin{tabular}{lcc}
\hline & Before EP & After EP \\
\hline GPx $(\mathrm{U} / \mathrm{ml})$ & $0.0298 \pm 0.000371$ & $0.0271 \pm 0.000434^{* *}$ \\
SOD $(\mathrm{U} / \mathrm{ml})$ & $0.914 \pm 0.0289$ & $0.767 \pm 0.0362^{*}$ \\
GSH $(\mathrm{RFI})$ & $30.195 \pm 8.265$ & $5.453 \pm 0.933^{* *}$ \\
\hline
\end{tabular}

The data are expressed as mean $\pm \mathrm{SD} ;{ }^{*} p \leq 0.05 ;{ }^{* *} p \leq 0.002$. EP, exercise period; GPx, glutathione peroxidase; SOD, superoxide dismutase; GSH, glutathione; $\mathrm{U} / \mathrm{ml}$, units per $\mathrm{ml}$; RFI, relative fluorescence intensity. on a density gradient, using a commercially available red cell lysing solution, Optilyse B (Beckman Coulter). The cell labelling and membrane fixation/permeabilization procedures were done by standard methods; the cell staining was performed as described in (Babusikova et al. 2008). We used monoclonal antibodies targeting membrane antigens: anti-CD45-ECD (Beckman Coulter), anti-CD16-FITC (Beckman Coulter), anti-CD11b-PE (Miltenyi Biotec), anti-CD3-FITC (Miltenyi Biotec), anti CD4-PE (Miltenyi Biotec), anti-CD8-APC (Miltenyi Biotec), anti-CD25Pacific Blue (ExBio Praha), anti-CD19-FITC (Miltenyi Biotec) and anti-CD56-PE (Beckman Coulter), and FACS analysis was performed by FACS Canto II flow cytometer (BD Biosciences, San Jose, CA). The data were analysed using FCS Express 4.0 (De Novo Software). NK cells were identified as CD3-CD56 + cells. To determine the absolute number of NK cells, equal volumes $(100 \mu \mathrm{l})$ of Flow-Count Fluorospheres (Beckman Coulter, CA, USA) and cells were mixed, and the NK cell concentration was calculated according to the formula: NK cells/ $\mu \mathrm{l}=$ (count NK cells $\times$ concentration beads)/ (count beads).

\section{Statistical analysis}

The General Linear Model repeated measures (GLM-RM) procedure was used to determine the main effects on measured parameter responses to exercise. A statistical evaluation was performed using the SPSS 11.5 program (SPSS Inc., Chicago, IL, USA). Measured parameters were compared by paired and unpaired $t$-tests or Mann-Whitney tests and Wilcoxon tests, according to the data distribution. The results were expressed as the mean $\pm \mathrm{SD}$, unless otherwise specified. Differences were considered statistically significant at $p<0.05$.

\section{Results}

Physiological effects, antioxidant changes and stress hormones

The general and anthropometric characteristics of the study population are shown in Table 1.

After 2 weeks of Pilates exercise, all probands remained weight stable; neither did the percentage of their body fat change. Physical activity measured as the mean MET h/day and $24 \mathrm{~h}$ energy expenditure was higher during the intervention. The mean fasting glucose and insulin, cortisol, and dehydroepiandrosterone sulphate (DHEAS) levels were comparable before and after the intervention (Table 1).

We observed a statistically significant decrease in the activities of antioxidant enzymes SOD and GPx, as well as a statistically significant decrease in GSH levels (Table 2) before and after Pilates intervention. 


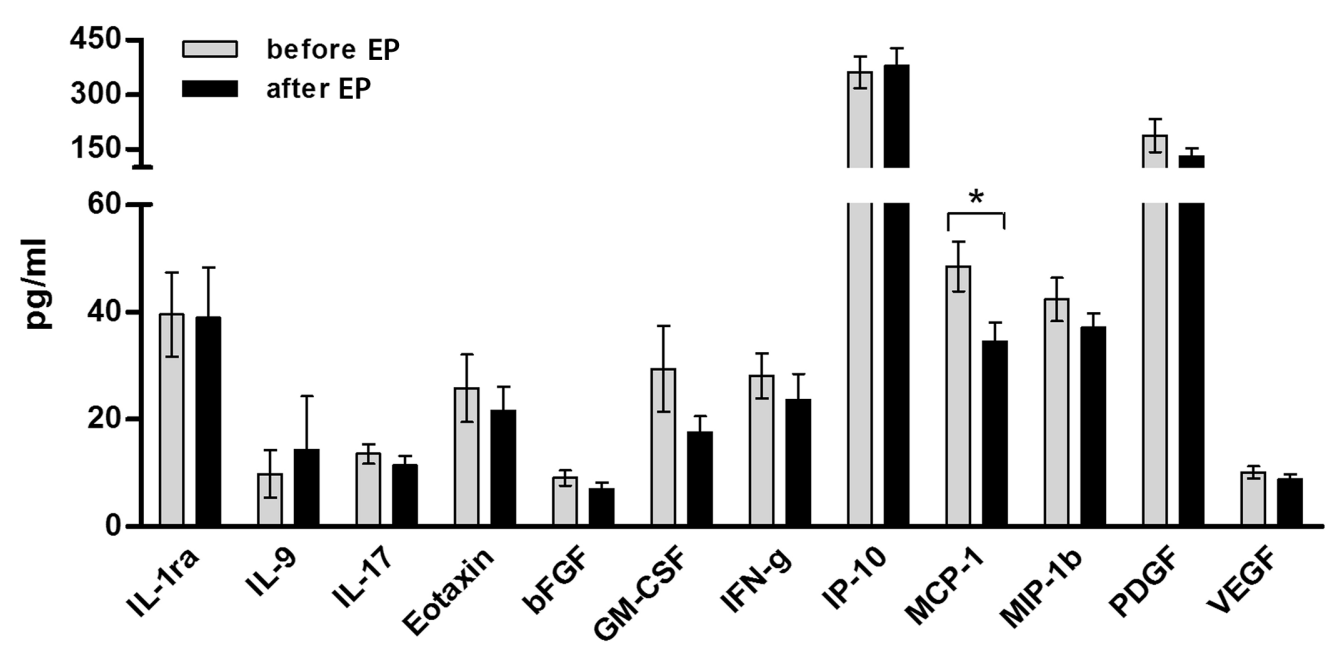

Figure 1. Cytokines and chemokines changes. Plasmatic levels of cytokines and chemokines measured before and after Pilates exercise period (EP). Data are means $\pm \mathrm{SD} .{ }^{*} p=0.005$. IL, interleukin; bFGF, basic fibroblasts growth factor; GM-CSF, granulocyte macrophage colony-stimulating factor; IFN, interferon; MCP-1, monocyte chemoattractant protein-1; IP-10, proinflammatory chemokine; PDGF, platelet-derived growth factor; VEGF, vascular endothelial growth factor.

\section{Cytokines and chemokines changes}

In the study, we measured the plasmatic levels $(\mathrm{pg} / \mathrm{ml})$ of 27 cytokines/chemokines of healthy volunteers obtained before and after two weeks of instructed Pilates exercise. We observed changes in 13 of them (Figure 1), as values of the rest were extrapolated beyond the standard range and were thus excluded from the evaluation. A statistically significant decrease $(p=0.005)$ in the pro-inflammatory chemokine MCP-1 (Figure 1) was observed, together with a reduction in MIP-1 $\beta$, PDGF and VEGF levels, almost approaching statistical significance $(p=0.071)$.

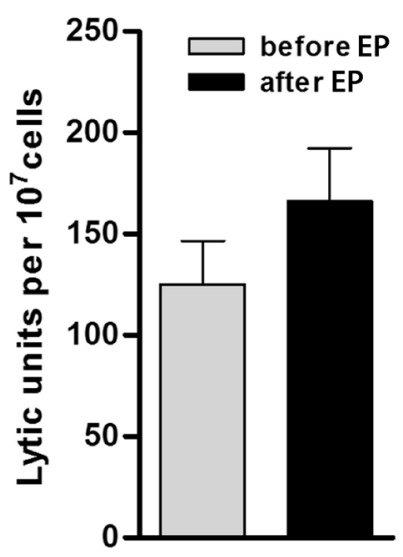

Figure 2. NK cell cytotoxic activity - amount of lytic units before and after exercise period (EP). A lytic unit is defined as the number of effector cells (PBMCs) required to lyse a predetermined number of target cells $($ K562 cells $)=\%$ specific lysis per $10^{7}$ cells. Data are means \pm SD.

\section{Nk cell cytotoxic activity}

NK cell cytotoxic activity had trend to increase after Pilates intervention $(p=0.152)$ as shown by amount of lytic units per $10^{7}$ cells (Fig. 2). In addition, percentage of specific lysis showed tendency to increase at all E: T ratios, with statistically significant increase $(p=0.02)$ at 25:1 ratio (Figure 3 ). Interestingly, neither percentage nor absolute counts of NK cells did change in our study (Figure 4). There were no significant changes in other PBMC subsets (data not shown).

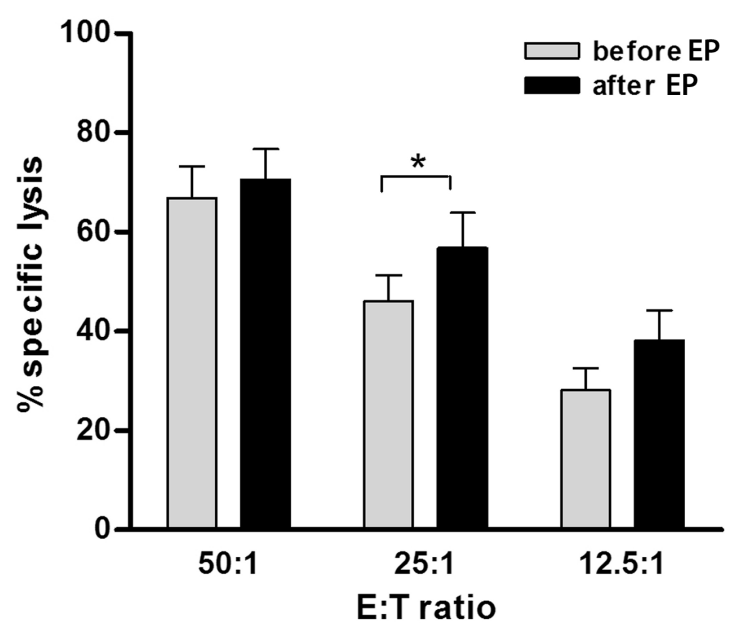

Figure 3. NK cytotoxic activity (E: T ratio) in effector cells (PBMCs) against target Nk cell cytotoxic activity - \% of specific NK cell lysis cells (K-562 cells). Statistically significant ratio E $: \mathrm{T}=25: 1$. Data are means \pm SD. ${ }^{*} p=0.02$; where $25 \%$ of the target cells are killed. 


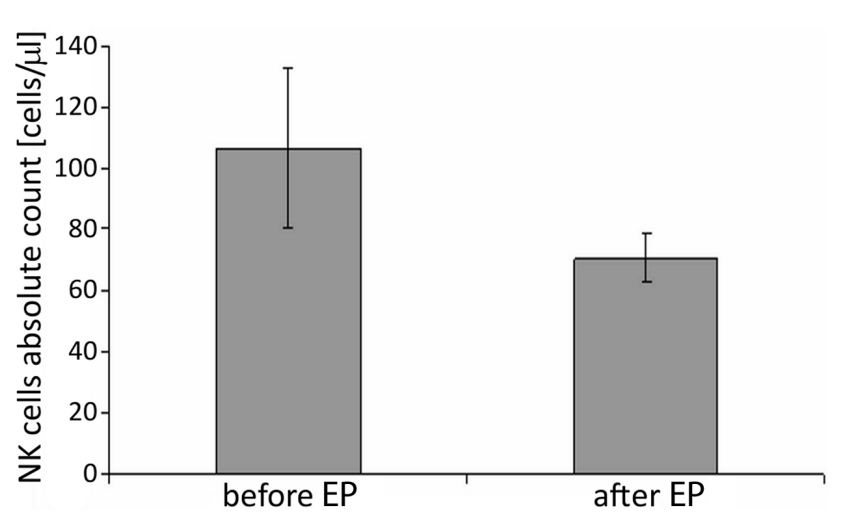

Figure 4. Absolute number of NK cells. Mean of absolute NK cells count $[\mathrm{cells} / \mu \mathrm{l}]$ before and after EP. Data are means \pm SEM.

\section{Discussion}

Many beneficial effects of Pilates exercise have gradually been revealed, such as an improvement in strength, flexibility, muscle coordination, posture, breathing, etc. (Phrompaet et al. 2011; Marandi et al. 2013). Recent studies have shown that long term Pilates exercise can improve osteoporosis, which is a problem in elderly people, and can improve the quality of life for patients with osteoporosis (Granacher et al. 2013; Küçükçakır et al. 2013).

In our study, we addressed some regulatory mechanisms which are activated by short term Pilates exercise and might be perceived as potentially prophylactic against cancer, since its mechanisms of action in cancer patients have not yet been described. It has only been observed that Pilates exercise decreased pain, improved mood (Keays et al. 2008), cardiopulmonary outcome (Eyigor et al. 2010) and patients were more interested in daily living activities, felt less irritated, less fatigue (Eyigor et al. 2010) and were more confident in communicating with family members and relatives without hesitation. Our observations showed reduction in MCP-1 plasma levels as well as tendency to reduce angiogenetic chemokines and increase of NK cell cytotoxicity, what has not yet been studied in Pilates interventions. To the best of our knowledge, our study is the first one dealing with short term Pilates and the only one among all (short term as well as long term Pilates interventions) describing its effects on immune parameters in human blood.

First, we observed, that 2 weeks Pilates intervention caused a significant decrease in pro-inflammatory chemokine Monocyte chemotactic protein-1 (MCP-1) plasma levels. This chemoattractant protein-1 (MCP-1/CCL2) is one of the key chemokines that regulate the migration and infiltration of monocytes/macrophages. Both MCP-1 and its receptor CCR2 have been demonstrated to be induced and involved in various diseases. As such, it has been shown to be a potential intervention point for the treatment of various diseases, including multiple sclerosis (Sørensen et al. 2004), rheumatoid arthritis (Hayashida et al. 2001), atherosclerosis (Kusano et al. 2004), and insulin-resistant diabetes (Sartipy and Loskutoff 2003). MCP-1 was also found to be associated with pancreatic cancer cachexia (Talbert et al. 2018). MCP-1 expression in tumour cells is significantly correlated with the extent of tumour-associated-macrophage (TAM) infiltration (Sato et al. 1995), and both MCP-1 and VEGF expressions have been positively correlated with TAM infiltration, angiogenesis, and poor survival in breast cancer (Valković et al. 2002; Deshmane et al. 2009). Thus, a decrease in these chemokines might be beneficial for breast cancer patients and survivors.

One of the mechanisms by which exercise and PA exert their beneficial effects is through peripheral immune system adaptations. The effects of voluntary wheel running on the neuroimmune reactions of mice were found to be modulated by MCP-1 (Spielman et al. 2017). Our finding that there was already a reduction in MCP-1 after 2 weeks of Pilates exercise complements the findings of others who reported that, in long term physical activity regimes, total levels of biomarkers of inflammation improved (Lunde et al. 2017). Similarly, endurance training (ET) reduced inflammatory markers (TNF- $\alpha$, IL-6), macrophage recruitment (MCP-1 and F4/80) and increased the IL-10/TNF- $\alpha$ ratio in plasma (Rocha-Rodrigues et al. 2017). MCP-1 and TNF- $\alpha$ also decreased in the group of healthy men who performed aerobic and resistance training on alternating days (AD) 4-6 d/wk (Ihalainen et al. 2018). MCP-1 has also been recognized as an angiogenic chemokine. Previous microarray analysis identified MCP-1 as a TGF- beta target gene in endothelial cells (Ma et al. 2006). In addition, other studies have revealed that MCP-1 participates in VEGF-mediated angiogenesis, increases vascular permeability and up-regulates VEGF expression (Hong et al. 2005).

Although other studied cytokines and chemokines (MIP$1 \beta$, PDGF and VEGF) showed only a trend in reduction approaching statistical significance after Pilates exercise, our findings reflect the complex regulatory mechanisms involved in inflammation and angiogenesis that seem to be positively influenced by Pilates exercise. Observed systemic decrease of these cytokines/chemokines could mediate beneficial effects also in cancer (Valković et al. 2002; Deshmane et al. 2009) and its frequent comorbidity diabetes (Sartipy and Loskutoff 2003).

Although, we observed a decrease in MCP-1 in the absence of weight/fat loss in healthy women, it is interesting that similar exercise settings in obese adults did not cause any changes in circulating chemokines, but only effected the chemokine receptors CCR2, CCR5, and CXCR2 expression on leukocytes (Barry et al. 2017). In our study, we did not observe any changes in peripheral blood subpopulations (data not shown); however, this was expected as Gustafson 
et al. (2017) showed a $122 \%$ increase of leukocytes immediately after exercise, peaking at $140 \%$ at the three-hour time point, for an endurance test, and returning back to base level after $24 \mathrm{~h}$. There is growing evidence that acute exercise can increase reactive oxygen species (ROS) production. In our system, we applied 2 weeks Pilates exercise corresponding to $18 \mathrm{METs} /$ week. We observed a decrease in SOD and GPx activities, as well as a decrease in GSH in erythrocytes, which suggests that our intensity levels approached vigorous intensity. There are similar observations in various other studies that have appeared recently. A treadmill maximal cardiopulmonary exercise test resulted in increased levels of lipid peroxidation and diminished superoxide dismutase activity (de Medeiros Lima et al. 2016). The 30-min. aerobic cycle ergometer test at an intensity of approximately $80 \%$ of $\mathrm{HR}_{\max }$, followed by recovery at RT, decreased erythrocytes' GPx activity in 18-year-old footballers (Sutkowy et al. 2017). Short-term monitoring of ultramarathon mountain race-induced oxidative stress showed a significant increase in static oxidation-reduction potential marker levels and a significant decrease in the capacity oxidation-reduction potential and GSH levels post-race compared with pre-race (Spanidis et al. 2017).

Our data also showed increased NK cell activity, although the number of NK cells did not change. We have already discussed the unchanged number of PB cells higher, and Evans et al. made a similar observation, exclusively for NK cells (Evans et al. 2015). In their study, they showed that exercise similarly affects the magnitude of the NK cell response in breast cancer survivors and physically similar women without a history of cancer. With this evidence, we can envisage similar NK cell response to Pilates both in healthy women and cancer survivors.

Moreover, we agree with others, who also observed exercise- dependent activation of NK cells cytotoxicity, specifically in breast cancer (Nieman et al. 1995; Fairey et al. 2005) and stomach cancer ( $\mathrm{Na}$ et al. 2000) survivors and believe that this can provide a mechanistic explanation for the protective effects of exercise on cancer patients (Idorn and Hojman 2016). Idorn and Hojman (2016) propose that exercise represents a potential strategy, as an adjuvant therapy, in cancer treatment, by improving NK cell functions. Since we do not assume different mechanisms leading to NK cell response in Pilates in comparison with other types of exercise, we deduce that STOTT Pilates might be one of the exercise types suitable for cancer patients as it can be easily adjusted to the degree of their physical performance.

To summarize, we found that MCP-1 proinflammatory and angiogenic chemokine plasma levels were decreased after a short period of Pilates exercise. The observed increase in NK cell cytotoxic activity may be the underlying mechanism by which Pilates might be beneficial for healthy people, improving their NK immune functions, and as such, it might be also useful in cancer patients and survivors, who often have impaired effectors of innate immunity. However, this presumption needs to be confirmed by specific canceroriented interventional studies.

Acknowledgments. The authors appreciate the skilful assistance of Ing. Jan Kusenda, CSc.; as well as Ms. Anna Kovarikova and Ms Margita (Pegy) Sulikova. This work was supported by the Slovak Research Agency (grant number VEGA 2/0092/16 and VEGA 2/0084/12).

\section{References}

Ainsworth BE, Haskell WL, Whitt MC, Irwin ML, Swartz AN, Strath SJ, Brien WLO, Bassett DR, Schmitz KH, Emplaincourt PO, et al. (2000): Compendium of physical activities : an update of activity codes and MET intensities. Med. Sci. Sport Exerc. 32, 498-504

https://doi.org/10.1097/00005768-200009001-00009

Angin E, Erden Z, Can F (2015): The effects of clinical pilates exercises on bone mineral density, physical performance and quality of life of women with postmenopausal osteoporosis. J. Back Musculoskelet Rehabil. 28, 849-858 https://doi.org/10.3233/BMR-150604

Babušíková O, Železníková T, Kirschnerová G, Kankuri E (2008): Hematogones in acute leukemia during and after therapy. Leuk. Lymphoma 49, 1935-1944 https://doi.org/10.1080/10428190701817274

Barry JC, Simtchouk S, Durrer C, Jung ME, Little JP (2017): Shortterm exercise training alters leukocyte chemokine receptors in obese adults. Med. Sci. Sports Exerc. 49,1631-1640 https://doi.org/10.1249/MSS.0000000000001261

Brenner DR, Yannitsos DH, Farris MS, Johansson M, Friedenreich CM (2016): Leisure-time physical activity and lung cancer risk: A systematic review and meta-analysis. Lung Cancer 95, 17-27 https://doi.org/10.1016/j.lungcan.2016.01.021

Deshmane SL, Kremlev S, Amini S, Sawaya BE (2009): Monocyte chemoattractant protein-1 (MCP-1): an overview. J. Interferon Cytokine Res. 29, 313-326 https://doi.org/10.1089/jir.2008.0027

Evans ES, Hackney AC, McMurray RG, Randell SH, Muss HB, Deal AM, Battaglini CL (2015): Impact of acute intermittent exercise on natural killer cells in breast cancer survivors. Integr. Cancer Ther. 14,436-445 https://doi.org/10.1177/1534735415580681

Eyigor S, Karapolat H, Yesil H, Uslu R, Durmaz B (2010): Effects of pilates exercises on functional capacity, flexibility, fatigue, depression and quality of life in female breast cancer patients: a randomized controlled study. Eur. J. Phys. Rehabil. Med. 46, $481-487$

Fairey AS, Courneya KS, Field CJ, Bell GJ, Jones LW, Mackey JR (2005): Randomized controlled trial of exercise and blood immune function in postmenopausal breast cancer survivors. J. Appl. Physiol. 98, 1534-1540 https://doi.org/10.1152/japplphysiol.00566.2004 
Friedenreich CM, Orenstein MR (2002): Physical activity and cancer prevention: etiologic evidence and biological mechanisms. J. Nutr. 132, 3456S-3464S https://doi.org/10.1093/jn/132.11.3456S

Friedenreich CM, Wang Q, Neilson HK, Kopciuk KA, McGregor SE, Courneya KS (2016): Physical activity and survival after prostate cancer. Eur. Urol. 70, 576-585 https://doi.org/10.1016/j.eururo.2015.12.032

Granacher U, Gollhofer A, Hortobagyi T, Kressig RW, Muehlbauer $\mathrm{T}$ (2013): The importance of trunk muscle strength for balance, functional performance, and fall prevention in seniors: A systematic review. Sport Med 43, 627-641 https://doi.org/10.1007/s40279-013-0041-1

Gustafson MP, DiCostanzo AC, Wheatley CM, Kim C-H, Bornschlegl S, Gastineau DA, Johnson BD, Dietz AB (2017): A systems biology approach to investigating the influence of exercise and fitness on the composition of leukocytes in peripheral blood. J. Immunother. Cancer 5, 30 https://doi.org/10.1186/s40425-017-0231-8

Hayashida K, Nanki T, Girschick H, Yavuz S, Ochi T, Lipsky PE (2001): Synovial stromal cells from rheumatoid arthritis patients attract monocytes by producing MCP-1 and IL-8. Arthritis. Res. 3, 118-126 https://doi.org/10.1186/ar149

Holmes MD, Chen WY, Feskanich D, Kroenke CH, Colditz GA (2005): Physical activity and survival after breast cancer diagnosis. JAMA 293, 2479-2486 https://doi.org/10.1001/jama.293.20.2479

Hong KH, Ryu J, Han KH (2005): Monocyte chemoattractant protein-1-induced angiogenesis is mediated by vascular endothelial growth factor-A. Blood 105, 1405-1407 https://doi.org/10.1182/blood-2004-08-3178

Cholujová D, Jakubíková J, Kubes M, Arendacká B, Sapák M, Ihnatko R, Sedlák J (2008): Comparative study of four fluorescent probes for evaluation of natural killer cell cytotoxicity assays. Immunobiology 213, 629-640 https://doi.org/10.1016/j.imbio.2008.02.006

Idorn M, Hojman P (2016): Exercise-dependent regulation of NK cells in cancer protection. Trends Mol. Med. 22, 565-577 https://doi.org/10.1016/j.molmed.2016.05.007

Ihalainen JK, Schumann M, Eklund D, Hämäläinen M, Moilanen E, Paulsen G, Häkkinen K, Mero AA (2018): Combined aerobic and resistance training decreases inflammation markers in healthy men. Scand. J. Med. Sci. Sports 28, 40-47 https://doi.org/10.1111/sms.12906

Irwin ML, Smith AW, McTiernan A, Ballard-Barbash R, Cronin K, Gilliland FD, Baumgartner RN, Baumgartner KB, Bernstein L (2008): Influence of pre- and postdiagnosis physical activity on mortality in breast cancer survivors: The health, eating, activity, and lifestyle study. J. Clin. Oncol. 26, 3958-3964 https://doi.org/10.1200/JCO.2007.15.9822

Keays KS, Harris SR, Lucyshyn JM, MacIntyre DL (2008): Effects of pilates exercises on shoulder range of motion, pain, mood, and upper-extremity function in women living with breast cancer: A Pilot Study. Phys. Ther. 88, 494-510 https://doi.org/10.2522/ptj.20070099

Kenfield S a, Stampfer MJ, Giovannucci E, Chan JM (2011): Physical activity and survival after prostate cancer diagnosis in the health professionals follow-up study. J. Clin. Oncol. 29, 726-732 https://doi.org/10.1200/JCO.2010.31.5226

Kruk J, Aboul-Enein HY (2006): Physical activity in the prevention of cancer. Asian Pacific J. Cancer Prev. 7, 11-21

Küçükçakır N, Altan L, Korkmaz N (2013): Effects of Pilates exercises on pain, functional status and quality of life in women with postmenopausal osteoporosis. J. Bodyw. Mov. Ther. 17, 204-211 https://doi.org/10.1016/j.jbmt.2012.07.003

Kusano KF, Nakamura K, Kusano H, Nishii N, Banba K, Ikeda T, Hashimoto K, Yamamoto M, Fujio H, Miura A, et al. (2004): Significance of the level of monocyte chemoattractant protein-1 in human atherosclerosis. Circ. J. 68, 671-676 https://doi.org/10.1253/circj.68.671

Lagerros YT, Mucci LA, Bellocco R, Nyrén O, Bälter O, Bälter KA (2006): Validity and reliability of self-reported total energy expenditure using a novel instrument. Eur. J. Epidemiol. 21, $227-236$ https://doi.org/10.1007/s10654-006-0013-y

Latey P (2001): The Pilates method: history and philosophy. J. Bodyw. Mov. Ther. 5, 275-282 https://doi.org/10.1054/jbmt.2001.0237

Lunde LK, SkareO, Aass HCD, Mamen A, Einarsdottir E, Ulvestad B, Skogstad M (2017): Physical activity initiated by employer induces improvements in a novel set of biomarkers of inflammation: an 8-week follow-up study. Eur. J. Appl. Physiol. 117, 521-532 https://doi.org/10.1007/s00421-016-3533-5

Ma J, Wang Q, Fei T, Han J-DJ, Chen Y-G (2006): MCP-1 mediates TGF- -induced angiogenesis by stimulating vascular smooth muscle cell migration. Blood 109, 987-994 https://doi.org/10.1182/blood-2006-07-036400

Marandi SM, Shahnazari Z, Minacian V, Zahed A (2013): A comparison between Pilates exercise and aquatic training effects on mascular strength in women with Mulitple sclorosis. Pakistan J. Med. Sci. 29, 285-289 https://doi.org/10.12669/pjms.291(Suppl).3518

de Medeiros Lima DJM, Mendes-Ribeiro AC, Martins MA, Mury WV, de Almeira Freire R, Monteiro WD, de Tarso Farinatti P, Matsuura C (2017): Erythrocyte nitric oxide availability and oxidative stress following exercise. Clin. Hemorheol. Microcirc. 65, 219-228 https://doi.org/10.3233/CH-16162

Meyerhardt JA, Giovannucci EL, Holmes MD, Chan AT, Chan JA, Colditz GA, Fuchs CS (2006): Physical activity and survival after colorectal cancer diagnosis. J. Clin. Oncol. 24, 3527-3534 https://doi.org/10.1200/JCO.2006.06.0855

Muscolino JE, Cipriani S (2004): Pilates and the „powerhouse“ - II. J. Bodyw. Mov. Ther. 8, 122-130 https://doi.org/10.1016/S1360-8592(03)00058-5

Na YM, Kim MY, Kim YK, Ha YR, Yoon DS (2000): Exercise therapy effect on natural killer cell cytotoxic activity in stomach cancer patients after curative surgery. Arch. Phys. Med. Rehabil. 81, 777-779 https://doi.org/10.1016/S0003-9993(00)90110-2

Nieman D, Cook V, Henson D, Suttles J, Rejeski W, Ribisl P, Fagoaga O, Nehlsen-Cannarella S (1995): Moderate exercise train- 
ing and natural killer cell cytotoxic activity in breast cancer patients. Int. J. Sports Med. 16, 334-337 https://doi.org/10.1055/s-2007-973015

Nocon M, Hiemann T, Müller-Riemenschneider F, Thalau F, Roll S, Willich SN (2008): Association of physical activity with allcause and cardiovascular mortality: a systematic review and meta-analysis. Eur. J. Cardiovasc. Prev. Rehabil. 15, 239-246 https://doi.org/10.1097/HJR.0b013e3282f55e09

Paffenbarger RS, Kampert JB, Lee I-M, Hyde RT, Leung RW, Wing AL (1994): Changes in physical activity and other lifeway patterns influencing longevity. Med. Sci. Sport Exerc. 26, 857-865 https://doi.org/10.1249/00005768-199407000-00008

Paglia DE, Valentine WN (1967): Studies on the quantitative and qualitative characterization of erythrocyte glutathione peroxidase. J. Lab. Clin. Med. 70, 158-169

Phrompaet S, Paungmali A, Pirunsan U, Sitilertpisan P (2011): Effects of pilates training on lumbo-pelvic stability and flexibility. Asian J. Sports Med. 2, 16-22 https://doi.org/10.5812/asjsm.34822

Pradhan AD, Manson JE, Rossouw JE, Siscovick DS, Mouton CP, Rifai N, Wallace RB, Jackson RD, Pettinger MB, Ridker PM (2002): Inflammatory biomarkers, hormone replacement therapy, and incident coronary heart disease: prospective analysis from the Women's Health Initiative observational study. JAMA 288, 980-987 https://doi.org/10.1001/jama.288.8.980

Quadrilatero J, Hoffman-Goetz L (2003): Physical activity and colon cancer. A systematic review of potential mechanisms. J. Sports Med. Phys. Fitness 43, 121-138

Rocha-Rodrigues S, Rodríguez A, Gonçalves IO, Moreira A, Maciel E, Santos S, Domingues MR, Frühbeck G, Ascensão A, Magalhães J (2017): Impact of physical exercise on visceral adipose tissue fatty acid profile and inflammation in response to a high-fat diet regimen. Int. J. Biochem. Cell Biol. 87, 114-124 https://doi.org/10.1016/j.biocel.2017.04.008

Rovio S, Kareholt I, Helkala E-L, Viitanen M, Winblad B, Tuomilehto J, Soininen H, Nissinen A, Kivipelto M (2005): Leisuretime physical activity at midlife and the risk of dementia and Alzheimer's disease. Lancet Neurol. 4, 705-711 https://doi.org/10.1016/S1474-4422(05)70198-8

Sartipy P, Loskutoff DJ (2003): Monocyte chemoattractant protein 1 in obesity and insulin resistance. Proc. Natl. Acad. Sci. USA 100, 7265-7270 https://doi.org/10.1073/pnas.1133870100

Sato K, Kuratsu J, Takeshima H, Yoshimura T, Ushio Y (1995): Expression of monocyte chemoattractant protein-1 in meningioma. J. Neurosurg. 82, 874-878 https://doi.org/10.3171/jns.1995.82.5.0874
Sekendiz B, Altun Ö, Korkusuz F, Akin S (2007): Effects of Pilates exercise on trunk strength, endurance and flexibility in sedentary adult females. J. Bodyw. Mov. Ther. 11, 318-326 https://doi.org/10.1016/j.jbmt.2006.12.002

Sørensen TL, Ransohoff RM, Strieter RM, Sellebjerg F (2004): Chemokine CCL2 and chemokine receptor CCR2 in early active multiple sclerosis. Eur. J. Neurol. 11, 445-449 https://doi.org/10.1111/j.1468-1331.2004.00796.x

Spanidis Y, Stagos D, Orfanou M, Goutzourelas N, Bar-or D, Spandidos D, Kouretas D (2017): Variations in oxidative stress levels in 3 days follow-up in ultramarathon mountain race athletes. J. Strength Cond. Res. 31, 582-594 https://doi.org/10.1519/JSC.0000000000001584

Spielman LJ, Estaki M, Ghosh S, Gibson DL, Klegeris A (2017): The effects of voluntary wheel running on neuroinflammatory status: Role of monocyte chemoattractant protein-1. Mol. Cell Neurosci. 79, 93-102 https://doi.org/10.1016/j.mcn.2016.12.009

Sutkowy P, Woźniak A, Boraczyński T, Boraczyński M, MilaKierzenkowska C (2017): The oxidant-antioxidant equilibrium, activities of selected lysosomal enzymes and activity of acute phase protein in peripheral blood of 18 -year-old football players after aerobic cycle ergometer test combined with ice-water immersion or recovery at room temperature. Cryobiology 74, $126-131$ https://doi.org/10.1016/j.cryobiol.2016.11.004

Talbert EE, Lewis HL, Farren MR, Ramsey ML, Chakedis JM, Rajasekera P, Haverick E, Sarna A, Bloomston M, Pawlik TM, et al. (2018): Circulating monocyte chemoattractant protein-1 (MCP-1) is associated with cachexia in treatment-naïve pancreatic cancer patients. J. Cachexia Sarcopenia Muscle 9, 358-368 https://doi.org/10.1002/jcsm.12251

Tuomilehto J, Lindstrom J, Eriksson JG, Valle TT, Hamalainen H, Ilanne-Parikka P, Keinanen-Kiukaanniemi S, Laakso M, Louheranta A, Rastas M, et al. (2001): Prevention of type 2 diabetes mellitus by changes in lifestyle among subjects with impaired glucose tolerance. N. Engl. J. Med. 344, 1343-1350 https://doi.org/10.1056/NEJM200105033441801

Valković T, Dobrila F, Melato M, Sasso F, Rizzardi C, Jonjić N (2002): Correlation between vascular endothelial growth factor, angiogenesis, and tumor-associated macrophages in invasive ductal breast carcinoma. Virchows Arch. 440, 583-588 https://doi.org/10.1007/s004280100458

Wells C, Kolt GS, Bialocerkowski A (2012): Defining pilates exercise: A systematic review. Complement. Ther. Med. 20, 253-262 https://doi.org/10.1016/j.ctim.2012.02.005

Received: November 20, 2017

Final version accepted: February 13, 2018 